Keywords:

Timber volume

Integration

Revolution solid

Decurrent

Historic:

Received 15/03/2017

Accepted 24/05/2017

Palavras chave:

Volume de madeira

Integração

Revolução sólida

Decurrente

+Correspondência: hattisbeltran@gmail.com

DOI:

\section{VOLUME AND TAPER EQUATIONS FOR COMMERCIAL STEMS OF Nothofagus obliqua AND N. alpina}

ABSTRACT: Timber volume of standing trees is essential information for management decisions. The increasing need to optimize the potential capacity of forests maintaining their conservation, requires the quantification of the different potential possible timber products. The aim was to adjust taper equations to determine volumes of different timber products for commercial stems of Nothofagus alpina and $N$. obliqua. Trees of both species were randomly selected in harvesting areas of Lanin National Park (Argentina). Trees were felled and cut into commercial logs, measuring diameter with bark at different heights up to the beginning of the crown, and for each tree the diameter at breast height and total height. Five taper equations were selected and non-linear regression processes were employed for the fittings. We obtained the volume through the integration of the stem profile equation and the rotation in the space thereof through solid of revolution. The Bennet and Swindel (1972) model was selected for both Nothofagus species, obtaining similar equation parameters and differences were observed at the top of the stems of larger trees. For this the use of an integrated model is not recommended. With the obtained equations it is possible to: (i) estimate-volume at different heights and for different commercial diameters, and (ii) predict the height at which both species reach to a certain diameter. The model presented some statistical limitations (e.g. multicollinearity), however, the fitting of the equation and the easy understanding of the outputs support it as a useful tool in a broad range of forest applications.

\section{EQUAÇÕES DE AFILAMENTO E VOLUME PARA TAMANHOS COMERCIAIS DE Nothofagus obliqua E N. alpina}

RESUMO: O volume de madeira das árvores em pé é uma informação essencial para as decisões de gestão. A crescente necessidade de otimizar a capacidade potencial das florestas mantendo sua conservação, requer a quantificação dos diferentes possíveis produtos de madeira possíveis. $\mathrm{O}$ objetivo era ajustar equações de afilamento para determinar volumes de diferentes produtos de madeira para hastes comerciais de Nothofagus alpina e N. obliqua. As árvores de ambas as espécies foram selecionadas ao acaso nas áreas de colheita do Parque Nacional Lanin (Argentina). As árvores foram derrubadas e cortadas em troncos comerciais, medindo o diâmetro com a casca em diferentes alturas até o início da coroa, e para cada árvore o diâmetro na altura do peito e altura total. Foram selecionadas cinco equações cônicas e foram empregados processos de regressão não-linear para ajustar. Obtivemos o volume através da integração da equação do perfil do caule e da rotação no seu espaço através do sólido da revolução. O modelo de Bennet e Swindel (1972) foi selecionado para as duas espécies de Nothofagus, obtendo parâmetros de equação semelhantes e observando-se diferenças no topo das hastes de árvores maiores. Portanto, o uso de um modelo integrado não é recomendado. Com as equações obtidas é possível: (i) estimar o volume em diferentes alturas e para diferentes diâmetros comerciais, e (ii) prever a altura em que ambas as espécies atingem um determinado diâmetro. $O$ modelo apresentou algumas limitações estatísticas (por exemplo, multicolinearidade), no entanto, o ajuste da equação e a compreensão fácil das saídas o suportam como uma ferramenta útil em uma ampla gama de aplicações florestais.

' Universidad Nacional del Comahue, Consejo Nacional de Investigaciones Científicas y Técnicas - San Martin de los Andes, Neuquén, Argentina

2 Universidad Nacional del Comahue, Administración de Parques Nacionales - San Martin de los Andes, Neuquén, Argentina

${ }^{3}$ University of Sydney - Sydney, Nova Gales do Sul, Australia

${ }^{4}$ Consejo Nacional de Investigaciones Científicas y Técnicas - San Martin de los Andes, Neuquén, Argentina 


\section{INTRODUCTION}

Lanin National Park (Argentina) has a long tradition in forest management of mixed forests of Nothofagus alpina Poepp. et Endl. (sensu N. nervosa Phill (Dim. et Mil.)) commonly named raulí and $N$. obliqua (Mirb.) Oerst commonly named roble pellín, and recently, in-situ and ex-situ plantation tests begun. These species are regionally considered as the best potential alternative species for commercial plantations. To date, exotic species (e.g. Pinus contorta Douglas ex Lauden), pino ponderosa ( $P$. ponderosa Douglas ex C. Lawson) y pino oregón (Pseudotsuga menziesii Mirb. Franco) are employed in plantations, however, native Nothofagus species are prefered due to the small commercial benefits (e.g. growth and timber quality) and the negative impacts over the native flora and fauna of the exotic trees.

The approach to forest management has shifted towards a multifunctional vision of the forest considering: (i) integration of biodiversity conservation in forest management process, (ii) characterization and maintenance of the multifunctionality of forests, (iii) the effective participation of stakeholders, and (iv) the use of new technologies (GÓMEZ GARCÍA et al. 20I6). In these sense, the development of new tools for forest management planning allowed to improve the current silvicultural proposals.

The hardest task to achieve during forest inventories is to estimate the individual volume of trees and classified it into the different timber products for local markets (MARTÍNEZ PASTUR et al. 2000). The increasing needs to optimize the timber potential of the forests, requires the quantification of the different possible timber products (ANDRADE, 2014). Therefore, it is critical to use biometric tools to promote appropriate silvicultural planning, and encourage sustainable use of forests.

Usually, forest yield is calculated using volume values provided by the total forest standing trees. However, volume is very difficult to measure directly (even more so when trees are standing) for this, volume is generally estimated from one or more variables that are positively correlated, such as height and diameter at breast height (GREGOIRE et al. 1986, WIANT et al. 1992). Stand volume can be obtained from individual tree models, resulting from the addition of all individual trees. However other models provide predictions at stand level directly (HARI, 1996).

Total tree volume can be estimated from volume equations (CHAUCHARD et al. 2005) which are useful and accessible; nevertheless, these functions only allow to estimate the total values for the tree without classifying the data in potential timber products that can be obtained along the stem (PRODAN et al. 1997, MENÉNDEZ-MIGUÉLEZ et al. 20l4). One of the purposes of the managers is to perform a more efficient use of the forests, considering different alternatives for the timber products obtaining through different harvesting proposals (JUNIOR et al, 20I2, CHAVES et al. 20I4). In this sense, the information about different wood products is an advantage during forest planning resulting in a more efficient use during the production chain, as well as maximizing benefits and reducing the impact caused by market fluctuations of certain products (DOS REIS et al. 2016). To overcome this issue, stem profile equations have been proposed, which allows to estimate the diameter of a tree at any height and vice-versa (CLUTTER et al. 1983), and from mathematical conversions of these equations, total volume of each product can be estimated.

A taper equation is defined as the diameter reduction rate of the tree stem from the base toward the apex, which determines a form of thereof (CRECHI et al. 2009, SOUZA et al. 2016). The outputs generate more precise volume estimations, and are more efficient their use to build growth and yield models and sawmill simulators (GEZAN et al. 2009). There are several types of equations (KOZAK, 2004; SÁNCHEZ GONZÁLEZ et al. 2007; POMPA GARCÍA; SOLÍS MORENO, 2008; GEZAN et al. 2009; ANDRADE, 20I4), where the most commonly employed independent variables were: diameter at breast height $(\mathrm{DBH})$, tree height, crown ratio, and pairs of diameter/height along the stem (HANN et al. 1987). These variables are easy and are standard measurements during forest inventories. To construct taper equations, it was required data from individual trees, which can derived from models of longitudinal structure or multiple measurements (diameter and height data pairs) of each individual.

To date, stem profile models for Nothofagus are developed both in Argentina and Chile. In Argentina, a taper model for $N$. pumilio was constructed, where site index was added as an independent variable (CELLINI et al. 2002, MARTÍNEZ PASTUR et al. 1997, CELLINI et al. 20I2). In Chile, spline functions were developed for $N$. pumilio (TRINCADO; VIDAL, 1999) and taper models for saplings of $N$. obliqua, $N$. alpina and $N$. dombeyi (GEZAN et al. 2009), but it has been recommended to use in $\mathrm{DBH}<50$ $\mathrm{cm}$ for $\mathrm{N}$. alpina and $\mathrm{DBH}<60 \mathrm{~cm}$ for $N$. obliqua. Regional changes in taper equations for $N$. obliqua were also studied. These differences in growth patterns (GEZAN et al. 2009, ATTIS BELTRÁN et al. 20I5) supporting the idea to develop specific stem profile functions for Nothofagus alpina and $N$. obliqua in Lanin National Park. For this, the aim was to adjust taper equations to determine volumes of different timber products for commercial stems of $N$. alpina and $N$. obliqua.

\section{MATERIAL AND METHODS}

\section{Study area}

The distribution range of Nothofagus obliqua is located between $33^{\circ}$ and $41.5^{\circ} \mathrm{SL}$, while $N$. alpina covers 
a slightly narrower latitudinal range between $35^{\circ}$ and 40.5 SL (DONOSO et al. 1993; SALAS; GARCÍA, 2006). The sampling was performed within the basin of the lakes Lácar and Nonthué ( $40^{\circ} 07^{\prime} \mathrm{SL}-71^{\circ} 27, \mathrm{WL}$ to $40^{\circ} 07^{\prime}$ $\left.\mathrm{SL}-71^{\circ} 39, \mathrm{WL}\right)$ covering 1,500 hectares where forest management units of the Reserve of Lanín National Park are located in the province of Neuquén (Argentina). The forests are dominated by pure and mixed Nothofagus forest types located between 600 and I,100 m a.s.l. (CHAUCHARD; SBRANCIA, 2003). Climate is temperate humid with average annual temperatures of $9^{\circ} \mathrm{C}$ and average rainfall of $1,800 \mathrm{~mm} \cdot \mathrm{yr}^{-1}$. The region was shaped by glaciers and later covered by volcanic ash (MERCER, 1976), and from this process emerged the dominant soils developed with the Holocene volcanic ash, and belonging to the order Andisols. They present a sequence of horizons O-A-Bw-C or sequences of these horizons because of successive ash deposits which resulted buried soils (FERRER et al. 199I, FRUGONI et al. 2005).

\section{Data}

Trees of $N$. alpina $(n=84)$ and $N$. obliqua $(n=98)$ were randomly selected in the harvesting areas and close unharvested areas in order to cover all the site qualities gradient. The sampling was designed to cover all the diameter and height distribution, including only trees with no visible damage or widespread diseases. Trees were cut and the following variables were measured in each tree: $\mathrm{DBH}$ in $\mathrm{cm}$ and total height in $\mathrm{m}(\mathrm{H})$. After that, commercial stem (from the stump cut to the bottom part of the crown) was divided into timber logs (2.2 to $5.0 \mathrm{~m}$ length) according to the market demands. In each cut, diameter and height data pairs ( $d-h)$ were taken. To detect possible anomalies in the data scatter plot between relative diameters and height (d-h data pairs related to $\mathrm{H}$ ) were examined.

(i) Polynomial:

$d=b_{1} D B H \frac{H-h}{H-1.3}+b_{2}(H-h)(h-1.3)+b_{3} H(H-h)(h-1.3)+b_{4}(H-h)(h-1.3)(H+h+1.3)+\varepsilon$

$d=D B H \sqrt{b_{1}\left(\frac{H-h}{H}\right)+b_{2}\left(\frac{H-h}{H}\right)^{2}+b_{3}\left(\frac{H-h}{H}\right)^{3}}+\varepsilon$

(ii) Potential:

$d=10 b_{1} D B H b_{2} H b_{3}(H-h)^{b_{4}}+\varepsilon$

$d=b_{1} D B H b_{2} H b_{3}(H-h)^{b_{4}}+\varepsilon$

(iii) Trigonometry:

$\mathrm{d}=\left[\frac{\ln \operatorname{sen} \frac{\pi}{2} \cdot \frac{h}{H}}{\ln \operatorname{sen} \frac{\pi}{2} \cdot \frac{1.3}{H}}\right]^{b_{1}+b_{2} \cdot \operatorname{sen}\left(\frac{\pi}{2} \cdot \frac{h}{H}\right)+b_{3} \cdot \cos \left(\frac{3 \pi}{2} \cdot \frac{h}{H}\right)+b_{4} \cdot \operatorname{sen}\left(\frac{\pi}{2} \cdot \frac{h}{H}\right)+b_{5} \cdot D B H+b_{6} \cdot\left(\frac{h}{H}\right) \cdot \sqrt{D B H}+b_{7} \cdot\left(\frac{h}{H}\right) \cdot \sqrt{H}}+\varepsilon$ 
values and multiplying by 100 (RMSE\% and bias \%) ([6] and [7]). Errors for each equation was the difference between observed and predicted value. Further, statistical errors were graphed through the predicted dependent variable (KOZAK, 2004). The residual serial correlation was examined graphically and using the Durbin-Watson statistic (Durbin; Watson, 195I), where, $n$ is the number of observations and, $y_{o}$ and $y_{e}$ are the experimental and predicted response values, respectively.

RMSE $=\sqrt{\sum \frac{\left(y_{o}-y_{e}\right)^{2}}{n}}$

Bias $=\sum\left(\frac{y_{0}-y_{e}}{n}\right)$

\section{Estimated volume from the stem profile function}

Through the integration of the stem profile function and the rotation in the space thereof, can be obtained through the revolution volume estimates [8] (CHAVES et al. 20I4). Through this function, volume can be estimated between two determined heights ( $h_{i}$ and $h_{j}$ ).

To assess the accuracy of the model to predict volume, first the volume of each tree logs cut up to the height of the beginning of crown was calculated using the Smalian formula (AVERY; BURKHART, 1994). The volume between the base and the beginning of crown was estimated by the sum of the individual volumes of each section (observed volume), and the volume of each sample was estimated with the function [8].

$V_{i j}=\frac{\pi}{4} \cdot \int_{\mathrm{hi}}^{\mathrm{hj}} \mathrm{f}(h)^{2} \cdot \mathrm{dh}$

Subsequently errors were calculated as the difference between the observed and predicted data by function [8], which were used for analysis of residual data. The following statistical data were calculated: mean absolute error (MAE), root mean square error (RMSE and RMSE \%) and bias. Besides this, graphs were made with: (i) errors estimates of stem volume according to $\mathrm{DBH}$ classes, and (ii) errors estimates of log volume depending on the average diameters.

\section{RESULTS}

Sample was composed by 84 trees of Nothofagus alpina and 98 trees of $N$. obliqua used for the fitting of the equations (Table I). Minimum and maximum diameters were upper and under the diameter of timber trees. The data distribution along diameter and height gradients for both species cover the natural range in the studied area (Table 2). Finally, the distribution of the data pairs of $d-h$ of the sample trees not presented anomalies in the scatter plots (Figure I).
The statistics obtained for the proposed equations showed good fittings and low bias values (Table 3). However, among the five tested equations, [I], [3] and [4] were those which obtained the least bias, in addition to presenting significance in all of its parameters (Table 4).

Bias gradients were analyzed along the stem (Figure 2) for both species through the root mean square percentage error (RMSE \%) and average bias

TABLE I Descriptive statistics of the trees that constitute the sample for the study. Standard deviation was presented between brackets.

\begin{tabular}{ccc}
\hline Variable & N. alpina & N. obliqua \\
\hline $\begin{array}{c}\text { Sample size } \\
\text { Average height } \\
(\mathrm{m})\end{array}$ & 84 & 98 \\
\hline $\begin{array}{c}\text { Maximum height } \\
(\mathrm{m})\end{array}$ & $26.9(5.95)$ & $26.7(6.91)$ \\
\hline $\begin{array}{c}\text { Minimum height } \\
(\mathrm{m})\end{array}$ & 39.6 & 45.1 \\
\hline $\begin{array}{c}\text { Average DBH } \\
(\text { years })\end{array}$ & 8.8 & 13.5 \\
\hline $\begin{array}{c}\text { Maximum DBH } \\
(\mathrm{cm})\end{array}$ & 122.0 & $48.09(17.78)$ \\
\hline $\begin{array}{c}\text { Minimum DBH } \\
(\mathrm{cm})\end{array}$ & 13.8 & 21.2 \\
\hline
\end{tabular}
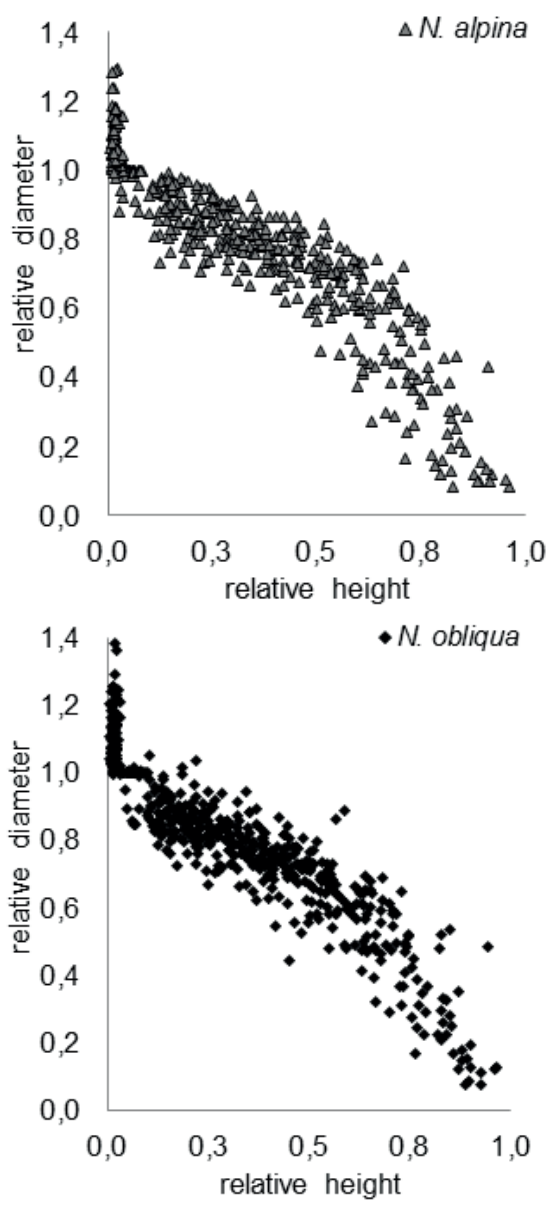

FIGURE I Dispersion of relative height according to relative diameter, of the trees used to fit the stem profile model. 
TABLE 2 Distribution of sample trees by $\mathrm{DBH}$ and height classes, where (a) N. obliqua and N. alpina

\begin{tabular}{ccccccccccc} 
DBH class & \multicolumn{10}{c}{ Total height class $(\mathrm{m})$} \\
\cline { 2 - 11 }$(\mathrm{cm})$ & I0-19.9 & $20-29.9$ & $30-39.9$ & $\geq 40$ & \multicolumn{3}{c}{ Total } \\
\cline { 2 - 11 } & (a) & (b) & (a) & (b) & (a) & (b) & (a) & (b) & (a) & (b) \\
\hline $20-29.9$ & 9 & 6 & 6 & 9 & 1 & - & - & - & 16 & 15 \\
$30-39.9$ & 6 & 2 & 14 & 18 & 1 & 5 & - & - & 21 & 25 \\
$40-49.9$ & 1 & 2 & 10 & 12 & 9 & 2 & - & - & 20 & 16 \\
$50-59.9$ & 1 & - & 12 & 2 & 4 & 4 & 1 & - & 18 & 6 \\
$60-69.9$ & 1 & - & 4 & 2 & 5 & 6 & - & - & 10 & 8 \\
$70-79.9$ & - & - & - & 2 & 4 & 5 & - & - & 4 & 7 \\
$80-89.9$ & - & - & 2 & - & 5 & 7 & 2 & - & 9 & 7 \\
\hline Total & 18 & 10 & 48 & 45 & 29 & 29 & 3 & 0 & 98 & 84 \\
\hline
\end{tabular}

TABLE 3 Statistics of the stem profile equation adjustment. $\mathrm{R}^{2}$ : coefficient of determination; $\mathrm{R}^{2}$ : adjusted coefficient of determination; SEE: standarrd error of estimate; MAE: mean absolute error.

\begin{tabular}{ccccccc}
\hline Model & $\mathrm{SP}$ & $\mathrm{R}^{2}$ & $\mathrm{R}_{\text {aj }}^{2}$ & $\mathrm{SEE}$ & $\mathrm{MAE}$ & bias \\
\hline \multirow{2}{*}[1]{} & N. alpina & 0.96 & 0.96 & 4.14 & 2.88 & -0.04 \\
& N. obliqua & 0.96 & 0.96 & 3.67 & $2.7 \mathrm{I}$ & 0.08 \\
{$[2]$} & N. alpina & 0.95 & 0.95 & 4.63 & 3.38 & 0.50 \\
& N. obliqua & 0.95 & 0.95 & 3.83 & 2.89 & 0.17 \\
& N. alpina & 0.96 & 0.96 & 4.53 & 3.31 & 0.04 \\
{$[3]$} & N. obliqua & 0.95 & 0.95 & 4.01 & 2.99 & -0.01 \\
& N. alpina & 0.96 & 0.96 & 4.53 & 3.31 & 0.03 \\
{$[4]$} & N. obliqua & 0.95 & 0.95 & 4.01 & 2.99 & -0.01 \\
& N. alpina & 0.97 & 0.97 & 3.89 & 2.75 & -0.60 \\
{$[5]$} & N. obliqua & 0.97 & 0.97 & 3.84 & 2.72 & -0.17 \\
\hline
\end{tabular}

(\%) for the three selected equations ([I], [3] and [4]). The RMSE\% of $N$. obliqua were lower than $13.6 \%$ and below $14.5 \%$ for $N$. alpina for the three equations, while the bias remained between -8.8 and $5.5 \%$ for $N$. obliqua and between -8.9 and $7.4 \%$ for $\mathrm{N}$. alpina. Equation [I] had the lowest RMSE\% values to relative heights between the beginning and the middle of the stem. The bias maintained between $-3.8 \%$ and $5.0 \%$ along the stem. The RMSE\% of N. alpina was lower than $14.0 \%$ for the three equations and the bias remained between $-8.9 \%$ and $7.4 \%$. Equation [I] presented, as for N. obliqua, the lowest RMSE\% values to relative heights between the beginning and the middle of the stem, and the bias was maintained between $-8.4 \%$ and $5.0 \%$. Equation [3] and [4] presented the same trend.

Based on the bias analyses and the general accuracy, the equation [I] was selected to estimate the stem profile of N. alpina and N. obliqua. Residuals plots (Figure
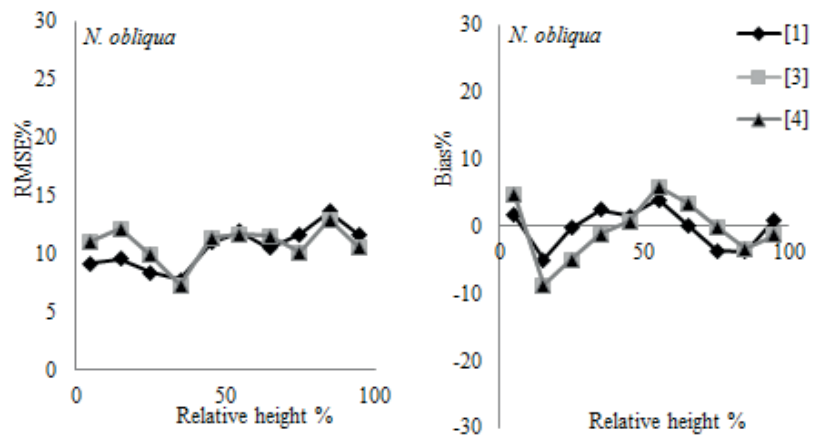

3) and Durbin-Watson statistic indicated that residual autocorrelation of the equation [I] was low for N. alpina $(D W=1.28)$ and for $N$. obliqua $(D W=1.02)$. Figure 4 showed the stem profile of two trees of $\mathrm{N}$. alpina and two trees of $\mathrm{N}$. obliqua, for heights of $35 \mathrm{~m}$ and $\mathrm{DBH}$ of $45 \mathrm{~cm}$, and heights of $20 \mathrm{~m}$ and $\mathrm{DBH}$ of $30 \mathrm{~cm}$.

With the obtained equations of stem profile [I] it is possible to obtainfind the volume function, producing therewith a solid of revolution of each tree stem, where, $\mathrm{V}_{\mathrm{ij}}$ : volume between the height ijd: diameter $(\mathrm{m})$ at height h, DBH: diameter at $1.3 \mathrm{~m}$, h: height $(\mathrm{m})$ at diameter d, $\mathrm{H}$ : total height $(\mathrm{m}) . \mathrm{b}_{1}$ to $\mathrm{b}_{7}$ : equation parameters.

Solving the derivative, the volume function was defined as [9]:

The values of the parameters for the volume equation (bI to b4) are shown for both species in Table 4. With these functions [10] which estimate the stem volume up to the beginning of crown for N. alpina and N. obliqua [10], we obtained an acceptable statistical precision and bias, not exceeding $10 \%$ of RMSE, and where MAE was lower than $0.15 \mathrm{~m}^{3}$ per individual in average (Table 5). If we compared the values of RMSE\% at different DBH classes, they not exceed $16 \%$, while bias $\%$ remained within the range of $-7 \%$ to $2 \%$ (Figure 5). With this tool it is possible to know the volume up to each diameter according to a specific commercial purpose and calculate it, using the inverse function determined for the stem profile, cleared in

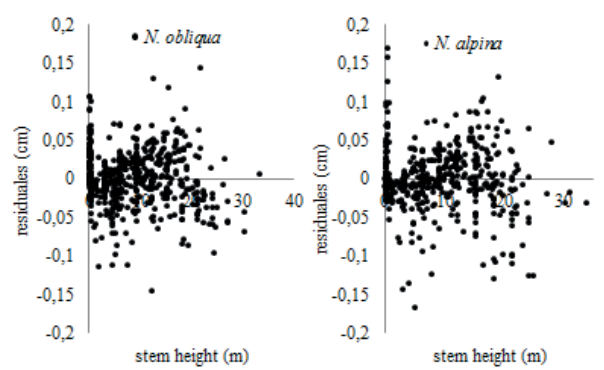

FIGURE 3 Bennett and Swindel (1972) [I] residuals for different stem height.
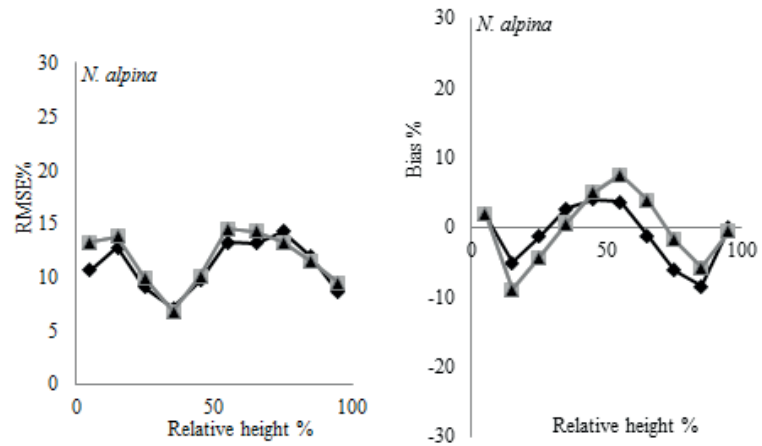

FIGURE 2 Goodness-of-fit statistics for diameter over bark estimation for different relative heights. RMSE\%: percentage root mean square error. [1]: Bennett and Swindel (1972); [3]: Demaerschalk (1972); [4]: Clutter (1980). 


$$
\begin{aligned}
& V_{i j}=\frac{\pi}{4} \int_{h_{1}}^{h_{2}} f\left(\frac{b_{1} D B H(H-h)}{-1.3+H}+b_{2}(H-h)(-1.3+h)+b_{3} H(H-h)(-1.3+h)+b_{4}(H-h)(-1.3+h)(1.3+H+h)\right)^{2} \\
& V_{h, h_{2}}=\frac{\pi}{4}\left[\frac{h^{7} T^{2}}{7}+\frac{h^{6} T Y}{3}+\frac{h^{5}\left(2 T Z+Y^{2}\right)}{5}+\frac{h^{4}(T U+Y Z)}{2}+\frac{h^{3}\left(2 U Y+Z^{2}\right)}{5}+h^{2} U Z+U^{2} h\right]_{h 1}^{h 2} \\
& Z=\left(-\frac{b_{1} D B H}{(-1.3+H}-b_{2} H+1.3 b_{2}+b_{3} H^{2}+1.3 b_{3} H+b_{4} H^{2}+1.3 b_{4} H+1.69 b_{4}\right) \\
& U=\left(\frac{b_{1} D B H H}{(-1.3+H)}-1.3 b_{2} H-1.3 b_{3} H^{2}-1.3 b_{4} H^{2}-1.69 b_{4} H\right) \\
& Y=\left(-b_{2}-b_{3} H\right) \\
& T=\left(-b_{4}\right) \\
& \mathrm{h}=\frac{-1}{81 \sqrt[3]{2 T^{3}}}\left(-531441 \mathrm{dT} 8+\left(\left(-531441 \mathrm{dT} 8+531441 \mathrm{~T}^{8} \mathrm{U}-177147 \mathrm{~T} 7 \mathrm{YZ}+39366 \mathrm{~T}^{6} \mathrm{Y}^{3}\right)^{2}+\right.\right. \\
& \left.\left.+4\left(2187 T^{5} \mathrm{Z}-729 \mathrm{~T}^{4} \mathrm{Y}^{2}\right)^{3}\right)^{1 / 2}+531441 \mathrm{~T}^{8} \mathrm{U}-177147 \mathrm{~T}^{7} \mathrm{YZ}+39366 \mathrm{~T}^{6} \mathrm{Y}^{3}\right)^{1 / 3}+ \\
& +\sqrt[3]{3}\left(2187 \mathrm{~T}^{5}-729 \mathrm{~T}^{4} \mathrm{Y}^{2}\right) / 81 \mathrm{~T}^{3}\left(-531441 \mathrm{dT} 8+\left(\left(-531441 \mathrm{dT} 8+531441 \mathrm{~T}^{8} \mathrm{U}-\right.\right.\right. \\
& \left.\left.-177147 T^{7} Y Z+39366 T^{6} Y^{3}\right)^{2}+4\left(2187 T^{5} Z-729 T^{4} Y^{2}\right)^{3}\right)^{1 / 2} \\
& \left.+531441 T^{8} \mathrm{U}-177147 \mathrm{~T}^{\mathrm{Y} Y Z}+39366 \mathrm{~T}^{6} \mathrm{Y}^{3}\right)^{1 / 3}-\frac{\mathrm{Y}}{3 \mathrm{~T}}
\end{aligned}
$$

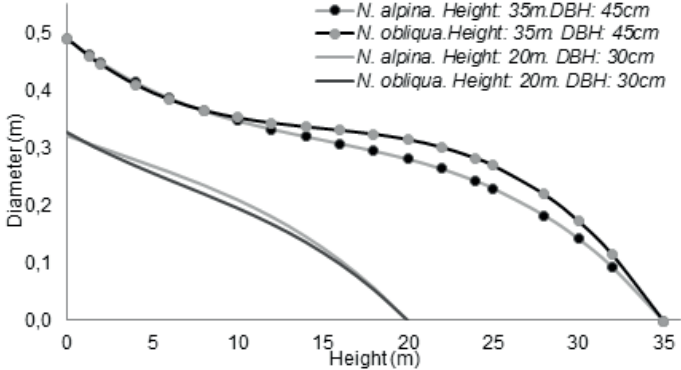

FIGURE 4 Stem profiles of Nothofagus alpina and N. obliqua, obtained with the equation [I] of Bennett and Swindel (1972).

the function [l] height $(\mathrm{h})$ to which a tree reaches a certain diameter (d) [15]. Thus the log volumes can be estimated according to different trade lengths and commercial diameters using function [10], where $\mathbf{Z}$ is [I I ], $\mathrm{U}$ is [I2], $\mathrm{Y}$ is [I3] and $\mathrm{T}$ is [ 14$]$.

Beside this, during the estimation of log volumes, RMSE\% values were close to $45 \%$ in logs of $0.20 \mathrm{~cm}$ diameter, but from larger diameters RMSE\% remained below $10-20 \%$ in the basal portion of the stem for both species. Bias\% estimated for the log volumes had similar behavior, being greatest in small diameters and in larger diameters for $N$. alpina (-I.7\% and $5.0 \%)$ and for $N$. obliqua (0.3\% and 3.0\%) (Figure 6).

\section{DISCUSSION}

The data obtained for both species fulfill the ranges of the studied variables (Table I). Adequate distribution of values for height and $\mathrm{DBH}$ classes were found by using equivalent data employed in other research for other Nothofagus species (CELLINI et al. 2002; GEZÁN et al. 2009). Similar data thresholds were found for both species at ranges of total height and $\mathrm{DBH}$, as well as the data distribution classified by height and DBH classes (Table 2). In addition it was also observed similarity pattern distributions

\begin{tabular}{|c|c|c|c|c|c|c|c|c|}
\hline Equation & Species & $b_{1}$ & $b_{2}$ & $\mathrm{~b}_{3}$ & $\mathrm{~b}_{4}$ & $\mathrm{~b}_{5}$ & $\mathrm{~b}_{6}$ & $\mathrm{~b}_{7}$ \\
\hline \multirow{2}{*}[\mathrm{I}]{} & N. alpina & $1.0250 * * *$ & 0.0009159 **** & -0.00005822 **** & 0.00002470 **** & - & - & - \\
\hline & N. obliqua & 1.0210 & 0.0003967 & -0.00005462 & 0.00003389 & - & - & - \\
\hline \multirow{2}{*}[2]{} & N. alpina & $3.6760 * * *$ & 2.737 ***** & -5.340 & - & - & - & - \\
\hline & N. obliqua & 4.6580 **** & 3.957 **** & -7.543 & - & - & - & - \\
\hline \multirow{2}{*}{ [3] } & N. alpina & -0.01438 **** & 0.9131 ***** & -0.7254 **** & 0.7387 **** & - & - & - \\
\hline & N. obliqua & 0.0539 **** & 0.9419 **** & -0.7068 **** & 0.6699 **** & - & - & - \\
\hline \multirow{2}{*}[4]{} & N. alpina & 0.9674 **** & 0.9131 **** & -0.7254 **** & 0.7387 ***** & - & - & - \\
\hline & N. obliqua & I.132 **** & 0.9419 **** & -0.7068 **** & 0.6700 **** & - & - & - \\
\hline \multirow{2}{*}[5]{} & N. alpina & 43.61 & 169.2 ***** & -43.43 & -14.33 & $0.7852 * * * *$ & -1.024 *** & -0.4346 **** \\
\hline & N. obliqua & 31.54 & $162.0 * * * *$ & -31.96 & 20.36 & 0.4895 **** & -2.036 **** & -0.3278 **** \\
\hline
\end{tabular}
between scatter plots of relative heights in relation to relative diameters for the studied species (Figure I).

The selection of the best equation for each species was based on multi-criteria, as was stated before. This was convenient, due to all models had higher coefficient of determinations (Table 3), however along the nonlinear adjustment the selection decisions should not only be made based on $\mathrm{R}^{2}$ values, although this measurement gives an intuitive idea of how the variability explains a

TABLE 4 Estimated parameters of the stem profile equations ( $(* * * *=p$-value $<0.00 \mathrm{I}$ ) 
TABLE 5 Statistics for error analyses in the volume function [9]. RMSE: root mean square mean error; RMSE\%: root mean square percentage error; MAE: mean absolute error.

\begin{tabular}{ccccc}
\hline SP & RMSE & $\begin{array}{c}\text { RMSE } \\
(\%)\end{array}$ & bias & MAE \\
\hline N. obliqua & 0.19 & 9.19 & -0.04 & 0.13 \\
N. alpina & 0.21 & 9.73 & -0.06 & 0.14 \\
\hline
\end{tabular}
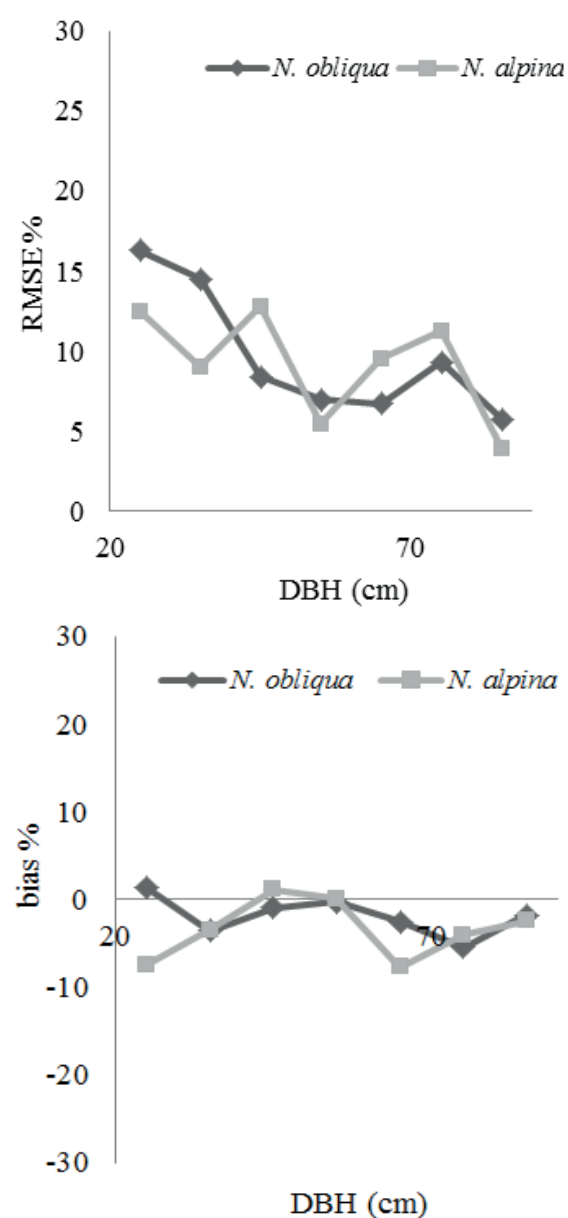

FIGURE 5 Statistics for the stem volume estimation using Bennett and Swindel (1972) equation. RMSE\%: percentage root mean square error.

particular fitting. Thus, we given a greater importance in the decision to the statistical error, the significance of the equation parameters and the residual dispersion analyses. Therefore, three adjusted equations were chosen out of the five initial candidates ([I], [3] and [4]) due to their lowest error values, greater accuracy, and especially because $N$. obliqua and $N$. alpina presented good significance for all the studied parameters. Particularly, model [5]can be successfully adapted to local conditions and different tree species by changing one or more of the three components, to produce models with better predictive ability (KOZAK, 2004).
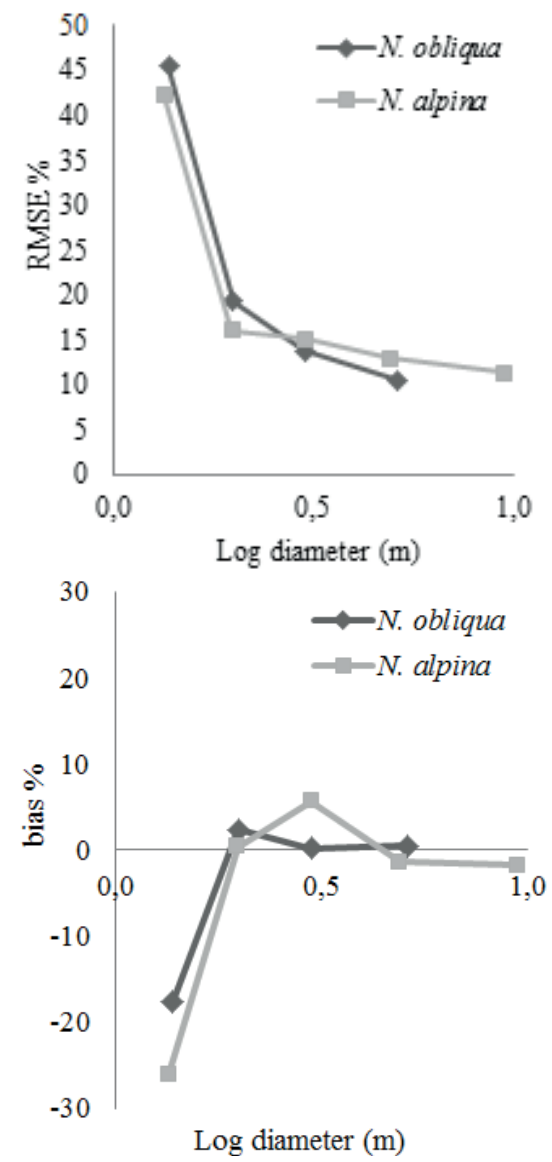

FIGURE 6 Statistics for the log volume estimation using Bennett and Swindel (1972) equation. RMSE\%: percentage root mean square error.

The adequate prediction of the stem basal section is very important because it is where the greatest amount of wood quality is located. RMSE\% and bias\% behavior depending on the relative height allowed to evaluate this premise and it was found that the behavior was similar between the two species. In this context, equation [I] was superior for $N$. alpina as well as $N$. obliqua among the 3 selected equations. This equation meets the condition that at the height of $\mathrm{DBH}$ the estimated diameter is equal to the $\mathrm{DBH}$ and at total height estimated diameter equals to zero. Due to we not used constrained models, an error were detected: parameter "bl" is not equal to I. Anyway parameter "bl" for both species is 1.025 and 1.021 , less than $\mathrm{I} \mathrm{cm}$ in a tree of $100 \mathrm{~cm}$ (close to $1 \%$ error in average).

In equation [I] for N. alpina RMSE\% values increased in the first quarter of the relative height without reaching unacceptable values. Probably the loss of precision in the basal portion of the stem was due to $N$. alpina database had two individuals with $\mathrm{DBH}$ greater than $1.20 \mathrm{~m}$, and both trees presenting the same outlayers magnifying the error values in this portion for these 
large diameters. It is common for old trees with large diameters, that they tend to have a markedly neiloide form in the basal portion of the stem (ROJO et al. 2005), but these trees are less frequent in the timber forests. However, to use the equations for bigger trees (up to I $\mathrm{m} \mathrm{DBH}$ ) and if subsequently it is necessary determine the volume, an alternative is to consider the shape of a cylinder of diameter equal to $\mathrm{DBH}$ between the beginning of the stem and the $\mathrm{DBH}$. Using this constrain, the estimation of the basal part of the stem will avoid the basal overestimation in the large old trees.

The small differences in the coefficients of the adjusted equations are reflected in stem profiles of Figure 4, which presented slightly different shapes, however, larger trees have different stem profiles as was discussed before. Nothofagus alpina showed a constant diameter decrease along the stem profile, while $N$. obliqua decrease is moderate at the beginning and then decrease more quickly at the end (Figure 4). However, among the studied trees, these differences may occurred within the crown, where the equations are not completely valid. For example, the beginning of the crown height was in average at $12 \mathrm{~m}$, and the differences in the stem profile are more evident only in the smaller trees (Figure 4). In future studies it must be considered adding the crown height variable for the equation adjustment as well as for the model selection.

There are many reasons for the discussed observed behaviours from those expected in the equations, many of them can be explained due to differences between expected and observed patterns. In this sense, native forests presented greater heterogeneity than plantations, due to natural irregularities along the stem cross section. Therefore wild forest rarely provides theoretical perfection for the equations, as was observed in the plantation trees. Irregularities in the shape are usually seen where tress has lost their branches by natural lopping, or where they still persist. Other reasons for irregularities in the shape of the stem can be due to fire damages, natural diseases or insect attacks. Most of the trees in the nature are eccentric in shape, so they are wider in one direction than in another (WEST, 2009). Also, this can be a response to a wind exposure or a result from the heterogeneous spatial arrangement among the trees (ROBERTSON, 199I) and their intraspecific competition.

As limitations and weaknesses we can mention that equation [I] contain also several terms with the same regressed variable resulting in multicollinearity problems. In addition, autocorrelation is not very high, but maybe can be improved using another methodology (e.g.
Rojo et al. 2005). Since the database contains multiple observations for each tree (i.e., hierarchical data), it is reasonable to expect autocorrelation within the residuals for each individual. The hierarchical structure may lead to a correlation between residuals of observations below $\mathrm{DBH}$ in the same way as residuals of observations above $\mathrm{DBH}$. Multicollinearity and autocorrelation are some of the most important problems that come when models are applied to forest data (ROJO et al. 2005)

Volume function [10] presented good outputs when stem volume and logs of different diameters were tested. The estimated value using the Smalian equation is not the real volume and includes an unknown error, but when the ratio among the two diameters (which is the most common in our samples) is higher than 0.82 , the error is less than I\% (WEST 2009). When we estimate stem volume, the values of the RMSE\% tends to decrease in trees of greater $\mathrm{DBH}$, which is desirable from a practical point of view and also from management, due to less mistakes were produced in the estimation of large trees. Usually, these trees $(40-60 \mathrm{~cm} \mathrm{DBH})$ are of highest value (CELLINI et al. 2002), and the bias\% tends of the equations were similar and presented lower values across the different lower DBH classes (Figure 5).

When volumes of different logs were estimated, RMSE\% and bias\% presented similarly outputs for full stems, but decrease towards the larger diameters (Figure $6)$. When the estimation considered each individual log, the error outputs were higher for diameters between $0.15 \mathrm{~m}$ and $0.20 \mathrm{~m}$ when were presented as percentage, but when the value was presented in cubic meters they are not significant. Nonetheless, the use of the model [I0] for $N$. alpina and $N$. obliqua is recommended for trees with $\mathrm{DBH}$ between $0.25 \mathrm{~m}$ and $1.00 \mathrm{~m}$, and medium log diameters between the same values.

Any natural dynamic process or silvicultural practice affecting the future shape of the trees, and has effect on tree growth modifying the stem profile (Souza et al. 2016). However, the shape equations showed enough flexibility to estimate the stem profiles of the sampled trees, which were not exempt to the influence of natural or anthropogenic phenomena. It is important to recognize that the stem diameter estimation at different heights, as well as the volume estimation, presented some bias when the models are applied at the beginning of the stem or at the crown. But the timber material is outside crowns. The other wood material is commonly used for lumber.

Thus it has been possible to simplify this inconvenience if we adjust stem profile functions especially for broadleaved, and not use those equations created for 
conifers. This results in a disadvantage, because estimates cannot be made within the crown height, although the volume can be obtained by difference with conventional models (CHAUCHARD et al., 2005), as it is the volume conformed by the products of lesser timber value.

To summarize the objective of this work, it was possible to obtain the stem profile equations and to estimate the volume for different timber products, including the most profitable timber products of the harvested trees. Some literature suggests that to use equations designed for conifers can be applied in broadleaf species, and they propose a transformation consisting in subtracting to each measured diameter the measure at the beginning of crown, however, this proposal do not solve the mentioned disadvantage (TRINCADO, 1996; TRINCADO; SANDOVAL, 2002).

Adjusted equations are useful management tools, which also allow knowing the growth and development of the stems for both species according to their dendrometric magnitudes. The biometric knowledge of the species under this study can be used for planning and the design of appropriate silvicultural proposals that allows to achieve sustained use of Nothofagus forests. Usually these trees were harvested for timber wood for sawmills and fire woods, however, one option is to increase the uses, allowing a significant increase in the incomes from a forest and improved forest management (CAMPOS et al. 2014). The equations developed attend to maintain a structural richness of the forest, allowing to estimate forest production and based on estimations, to determine extractability, so that the extraction does not exceed the growth. In addition, the classification of the product becomes an important tool to evaluate the role of forest and wood products, especially in light of in a climate change context, due to fixation and carbon sequestration (RODRÍGUEZ et al. 2015).

\section{CONCLUDING REMARKS}

Stem profile functions have been developed for Nothofagus alpina and N. obliqua in order to be applied in the basin of lakes Lacar and Nonthué. The equation chosen for each species was Bennett and Swindel (1972), and presented similar parameters between the two species, but with differences at the top of the stem in larger trees. For this, their use in these cases were not recommended. Volume functions were also obtained derived from the stem profile equations, being possible to estimate log volume at different heights and for different commercial diameters. Finally, a model to predict the height at which $N$. alpina or $N$. obliqua trees reaches at certain diameter was obtained. With these functions it is possible to determine volumetric existences in standing trees of $N$. obliqua and
N. alpina growing in the Lanín National Park, which can be used for a better forest management of these forests. The model presented some statistical limitations (e.g. multicollinearity), however, the fitting of the equation and the easy understanding of the outputs support it as a useful tool in a broad range of forest applications.

\section{REFERENCES}

ANDRADE, V.C.L. Modelos de taper do tipo expoente-forma para descrever o perfil do fuste de árvores. Pesquiza Florestal Brasileira, v.34, n.80, p. 27I-283, 2014.

ATTIS BELTRÁN, H.; CHAUCHARD, L.M.; MARTÍNEZ PASTUR, G. Curvas preliminares de índice de sitio para bosques puros y mixtos de Nothofagus alpina y Nothofagus obliqua en la Patagonia Argentina. Bosque, v.36, n.2, p.275-285, 2015.

AVERY, T.; BURKHART, H. Forest measurements. McGrawHill, New York. 33I pp. 1994.

BENNETT, F.A.; SWINDEL, B.F. Taper curves for planted slash pine. USDA Forest Service Research Note 179. 4 pp. 1972.

$\mathrm{BI}, \mathrm{H}$. Trigonometric variable-form taper equations for Australian Eucalypts. Forest Science, v.46, n.3, p. 397-409, 2000.

CAMPOS, B.P.F; BINOTI, D.H.B.; DA SILVA, M.L.; LEITE, H.G.; DA SILVA BINOTI, M.L.M. Effect of taper model used on the conversion of trees in boles into multiproducts. Scientia Forestalis, v.42, n. I04, p.5।3-520, 2014.

CELLINI, J.M.; GALARZA, M.; BURNS, S.L.; MARTÍNEZ PASTUR, G.; LENCINAS, M.V. Equations of bark thickness and volume profiles at different heights with easy-measurement variables. Forest Systems, v.2I, n.I, p.23-30, 2012.

CELLINI, J.M.; MARTÍNEZ PASTUR, G.; WABÖ, E.; LENCINAS, M.V. Modelos de perfil de tronco en Nothofagus pumilio (Poepp. et Endl.) Krasser y su utilización en el cálculo del volumen total. Investigación Agraria: Sistemas y Recursos Forestales, v.l I, n.2, p.245-262, 2002.

CHAUCHARD, L.; GONZÁLEZ PEÑALBA, M.; LARA, A. Familias de volumen individual para Nothofagus nervosa, N. obliqua y N. dombeyi. Acta del tercer Congreso Forestal Argentino y latinoamericano. Corrientes, 6 al 9 de septiembre, 2005.

CHAUCHARD, L.; SBRANCIA, R. Modelos de crecimiento diamétrico para Nothofagus obliqua. Bosque, v.24, n.3, p. 3-16, 2003.

CHAVES, S.; CARVALHO, L.C.E.R.; CALEGARIO, N.; SAVIAN, T.V.; DE LIMA, M.P.; SILVA, C.A.; NICOLETTI, M.F. Modelagem não linear mista para descrever o afilamento de árvores clonais de Eucalyptus sp. Scientia Forestalis, v.42, n. I04, p. 605-6I4, 2014. 
CLUTTER, J.L. Development of taper functions from variabletop merchantable volume equations. Forest Science, v.26, p.II7-120, 1980.

CLUTTER, J.L.; FORSTON, J.; PIENAAR, L.; BRISTER, G.; BAILEY, R. Timber Management: A quantitative approach. New York. John Wiley \& Sons. 333 pp. 1983.

CRECHI, E.; KELLER, A.; FASSOLA, H. Desarrollo de una ecuación de forma para la estimación de diámetros volúmenes a diferentes alturas en Grevillea robusta $A$. cultivado en Misiones, Argentina. XIII World Forestry Congress Buenos Aires, Argentina, 18-23 October, 2009.

DEMAERSCHALK, J. Converting volume equations to compatible taper equations. Forest Science, v.18, n.3, p.24I-245, 1972.

DONOSO, P.; DONOSO, C.; SANDOVAL, V. Proposición de zonas de crecimiento de renovales de roble (Nothofagus obliqua) y raulí (Nothofagus alpina) en su rango de distribución natural. Bosque, v.14, n.2, p. 37-55, 1993.

DOS REIS MARTINS, E.; DA SILVA BINOTI, M.L.M.; LEITE, H.G.; BINOTI, D.H.B.; DUTRA, G.C. Configuração de redes neurais artificiais para estimação do afilamento do fuste de árvores de eucalipto. Revista Brasileira de Ciências Agrárias (Agrária), v. I I, n. I, p. 33-38, 2016.

DURBIN, J.; WATSON G.S. Testing for serial correlation in least squares regression. Biometrika, Vol. 38, pp. I59-I77. I95I.

FERRER, J.A.; IRIZARRI, J.A.; MENDÍA, J.M. Estudio regional de suelos de la provincia de Neuquén. Consejo Nacional de Inversiones, Consejo de Planificación y Acción para el Desarrollo, Neuquén, Argentina. I59 pp. I99I.

FRUGONI, M.C.; RABINO, A.; CHAUCHARD, L. La distribución de los bosques de Nothofagus y su relación con los factores de sitio en una sub-cuenca de la Patagonia Andina. Acta del tercer Congreso Forestal Argentino y latinoamericano. Corrientes, 2005.

GEZAN, S.A.; MORENO, P.C.; ORTEGA, A. Modelos fustales para renovales de roble, raulí y coigüe en Chile. Bosque, v.30, n.2, p. 6I-69, 2009.

GOMEZ GARCÍA, E.; DIÉGUEZ ARANDA, U.; ÓZCELIK, R.; SAL CANDO, M.; CASTEDO DORADO, F; CRECENTE CAMPO, F.; CORRAL RIVAS, J.; ARIAS RODIL, M. Desarrollo de una función de perfil mediante modelos mixtos para Pinus sylvestris en Turquía: selección de parámetros fijos a expandir. Bosque, v.37, n.I, p. 159-167, 2016.

GREGOIRE, T.G.; VALENTINE, H.T.; FURNIVAL, G.M. Estimation of bole volume by importance sampling. Canadian Journal of Forest Research, v.16, n.3, p.554-557, 1986.

HANN, D.W.; RITCHIE, M.W. Height growth-rate of Douglasfir: a comparison of model forms. Forest Science, v.34, p. $165-175,1987$.

HARI, P. Idealization and concretization in construction of models applied to forest growth. The Science of the Total Environment, v. 183,: p. I79-185, 1996.
JUNIOR, M.Y.; NAKAJIMA, N.; ARCE, J.E.; MACHADO, S.A.; DRUSZCZ, J.P; HOSOKAWA, R.T.; DE MELLO, A.A. Funções de afilamento para plantios desbastados de Pinus taeda. Floresta, n.42, v. I, p. 169-176, 2012.

KOZAK, A. My last words on taper equations. The Forestry Chronicle, n.80, v.4, p.507-5I5, 2004.

MARTÍNEZ PASTUR, G.; CELLINI, J.; PERI, P.L.; VUKASOVIC, R.; FEERANDEZ, M. Timber production of Nothofagus pumilio forests by a shelterwood system in Tierra del Fuego (Argentina) Forest Ecology and Management, v.134, n. I, p. I53-162, 2000.

MARTÍNEZ PASTUR, G.; PERI, P.L.; VUKASOVIC, R.; VACCAR, S.; PIRIZ CARRILLO, V. Site index equation for Nothofagus pumilio Patagonian forest. Phyton, v. 6I, n. I/2, p. 55-60, 1997.

MENÉNDEZ-MIGUÉLEZ, M.; CANGA, E.; ÁLVAREZÁLVAREZ, P.; MAJADA, J. Stem taper function for sweet chestnut (Castanea sativa Mill.) coppice stands in northwest Spain. Annals of Forest Science, v.7I, p. 76I-770, 2014.

MERCER, J. Glacial history of southernmost South America. Quaternary Research, v. 6, p. 125-166, 1976.

POMPA GARCÍA, M.; SOLIS MORENO, R. Ecuación de volumen para el género Quercus en la región noroeste de Chihuahua, México. Quebracho, v. 16, p. 84-93, 2008.

PRODAN, M. Discurso pronunciado en la Facultad de Ciencias Forestales, Universidad Austral de Chile, Valdivia. Quebracho, v.4, p. 5I-55, 1993.

PRODAN, M.; PETERS, R.; COX, F.; REAL, P. Mensura forestal. Serie de investigación y evaluación en desarrollo sostenible. San José, Costa Rica. IICA, GTZ. $56 \mathrm{I}$ pp. 1997.

RENTERÍA, A. Sistema de cubicación para Pinus cooperi Blanco mediante ecuaciones de ahusamiento en Durango. Tesis de Maestría en Ciencias. Universidad Autónoma Chapingo. Chapingo, México. 77 pp. 1995.

ROBERTSON, A. Centroid of wood density, bole eccentricity, and tree-ring width in relation to vector winds in wave forests. Canadian Journal of Forest Research, v.21, p. 73-82, 1991.

RODRÍGUEZ, F.; LIZARRALDE, I.; BRAVO, F. Comparison of stem taper equations for eight major tree species in the Spanish Plateau. Forest Systems, v.24, n.3, p.034, 2015.

ROJO, A.; PERALES, X.; SÁNCHEZ-RODRIGUEZ, F.; ÁLVAREZ-GONZÁLEZ G.J.; VON GADOW, K. Stem taper functions for maritime pine (Pinus pinaster Ait.) in Galicia (Northwestern Spain). European Journal of Forest Research, v. I24, p. 177-186, 2005.

SALAS, C.; GARCÍA, O. Modelling height development of mature Nothofagus obliqua. Forest Ecology and Management, v.229, n. I-3, p. I-6, 2006. 
SÁNCHEZ GONZÁLEZ, M.; SÁNCHEZ MARTÍNEZ, M.; CAÑELAS REY DE VIÑAS, I. Modelo de predicción del calibre de bornizo mediante funciones de perfil del tronco. Cuaderno de la Sociedad Española de Ciencias Forestales, v.23, p.239-243, 2007.

SOUZA, R.R.; NOGUEIRA, G.S.; JÚNIOR, L.S.M.; PELLI, E.; DE OLIVEIRA, M.L.R.; ABRAHÃO, C.P.; LEITE, H.G. Forma de fuste de árvores de Eucalyptus em plantios com diferentes densidades iniciais. Scientia Forestalis, v.44, n. 109: 33-40, 2016.

TRINCADO, G. Modellierung der Schaftform von Fichten (Picea abies) und Buchen (Fagus sylvatica). Wissenchaftliche Arbeit zur Erlangung des Grades Magister der tropischen. 50 pp. 1996.
TRINCADO, G.; SANDOVAL, V. Algoritmos para la estimación de volúmenes comerciales. Quebracho, v. 9, p. I06-I I4, 2002.

TRINCADO, G.; VIDAL, J. Aplicación de interpolación "spline" cúbica en la estimación de volumen. Bosque, v.20, n.2, p. 3-8, 1999.

WEST, P.W. Tree and Forest Measurement. $2^{\text {nd }}$ Edition. New York: Springer. I9I pp. 2009.

WIANT, H.V.; WOOD, G.B.; GREGOIRE, T.G. Practical guide for estimating the volume of a standing sample tree using either importance or centroid sampling. Forest Ecology and Management, v.49, n.3, p. 333-339, 1992. 